\title{
An assessment of the effects and influences of the concept of entrepreneurial learning in Serbia:
}

\section{Процена ефеката и утицаја концепције предузетничког учења у Србији}

\author{
Marija N. Marčetić \\ Academy of Vocational Studies South Serbia, Leskovac, Serbia, e-mail: neimar.marija@gmail.com \\ Gordana T. Prlinčević \\ Academy of Vocational Studies South Serbia, Leskovac, Serbia, e-mail: gordanaprlinčević@yahoo.com \\ Biljana Grujić Vučkovski \\ Institute of Agricultural Economics, Belgrade, Serbia, e-mail: biljana_g@iep.bg.ac.rs
}

\begin{abstract}
It is difficult to estimate the quantity and quality of the necessary entrepreneurial knowledge and assess the effects of such entrepreneurship education, i.e. whether it has met the set criteria sufficiently. Empirical practice lacks empirical studies that would base the competences of entrepreneurial learning upon the direct assessment of learning outcomes, the outcomes related to the knowledge of opportunities for professional orientation and the knowledge of the business environment, the created framework picture of entrepreneurship, employment opportunities and obstacles. In this paper, the direct effect of entrepreneurial learning in a secondaryeducation and a higher-education institution of the economic path was estimated through a qualitative approach, after the established conceptual framework and furthermore through the respondents' answers to the survey questions. Therefore, a contribution was made by making a step forward in the evaluation of entrepreneurial learning through a direct assessment of the raised awareness of entrepreneurship. The indirect indicators used were the gender and the education level, i.e. the difference in the respondents' answers according to their respective gender and the school they are attending (secondary school or vocational school). The obtained results assess the level of the respondents' basic entrepreneurial culture and their knowledge, as well as entrepreneurial preferences.
\end{abstract}

Keywords: entrepreneurship, entrepreneurial learning, entrepreneurship education, evaluation JEL classification: A20, L26

Сажетак: Тешко је проценити квантитет и квалитет неопходног предузетничког знања, проценити ефекте предузетничке едукације, тј. да ли је у довољној мери задовољила задате критеријуме. У емпиријској пракси недостају радови који би компетенције предузетничког учења заснивали на директној процени исхода учења. Исхода који се односе на стицања знања о могућностима за професионалну оријентацију и познавање пословног окружења, створену оквирну слику о предузетништву. У раду је након установљеног концептуалног оквира, и даље кроз одговоре испитаника на анкетна питања, квалитативним приступом, оцењен директни ефекат предузетничког учења у средњој и високошколској установи економског опредељења. Дакле, дат је допринос кроз искорак направљен у евалуацији предузетничког учења путем директне процене подигнуте свесности о предузетништву. Индиректни

Paper was financed by the Ministry of Education, Science and Technological Development of the Republic of Serbia

Correesponding author 
индикатор који је коришћен је пол и ниво образовања, тј. разматрана је разлика у одговорима испитаника према полу и школи коју похађају (средња или висока). Добијени резултати процењују ниво основне предузетничке културе и знања испитаника као и предузетничке преференције.

Кључне речи: предузетништво, предузетничко учење, предузетничко образовање, евалуација JEЛ класификација: A20, L26

\section{Introduction}

To only limit oneself to one out of a large number of the definitions of entrepreneurship is not an easy task. Mainly, their common determinants are creativity, productivity and an initiative related to doing business. For the purpose of this research study, our focus will be on the definition of entrepreneurship as a mechanism through which knowledge is transformed into practical results (Xingjian, 2019). The most important determinant for us is that an entrepreneur is created, not born, and that entrepreneurship is his/her basic intellectual activity (Adebiyi, 2013). Such a concept of entrepreneurship leads to the conclusion that learning is necessary for entrepreneurship, and vice versa, entrepreneurship has its place in the educational system.

Furthermore, we come to the notion of entrepreneurial learning, as well as the notion of the entrepreneurship of the young. We shall first of all rely on the definition of entrepreneurship education given by the European Commission: "Entrepreneurship education should not be mixed with the general business and economic studies; its goal is to promote creativity, innovation and self-employment, and it can include the following elements: the development of the personal attributes and skills that make up the basis of the entrepreneurial spirit and behavior (creativity, a sense of initiative, risk-taking, autonomy, self-confidence, leadership, a team spirit and so on), raising pupils'/students' awareness of self-employment and entrepreneurship as possible career options; work on concrete entrepreneurial projects and activities; ensuring special business skills and types of knowledge of how to establish an enterprise and run it successfully."

Entrepreneurship education is aimed at making young people familiar with the bases of entrepreneurship, as well as drawing attention to the importance of this issue. However, in order for entrepreneurship to be used as a development opportunity for the economy, it is necessary to determine what encourages young people to become entrepreneurs (Bjekić \& Strugar Jelača, 2019). Entrepreneurship education should train in social skills, creativity and innovativeness, searching for opportunities, becoming familiar with business communication and administration, and should inspire to action. Young people should also become familiar and equipped with entrepreneurial skills through the education process (e.g. the recognition of the right opportunity, business planning, etc.). Preparatory education in this field would help the young to develop the entrepreneurial competences that will later be beneficial for their future job or, yet, while they work on an entrepreneurial team (ErićNielsen et al., 2019). The explanation for an educational intervention like this one lies in the fact that there are market distortions (Miletić et al., 2018) preventing young people from accessing the labor market easily unless they have the necessary knowledge, skills and abilities to correctly assess an entrepreneurial opportunity (Mušikić et al., 2017b). 
As far as the definition of the entrepreneurship of young people is concerned, despite the insufficient consensus in the literature, we will rely on the paper by Chigunta (2001) and Schnurr and Newing (1997), which defines it as "a practical application of the entrepreneur's qualities, such as initiative, innovation, creativity and risk taking by using the needed skills necessary for success in the given environment. This definition assumes that by their very decision to start a job young people utilize their full potential, define the problem, identify a solution and find resources to solve them, which helps their selfconfidence to grow and helps them to take up an active role in their communities (International Labor Organization, 2015).

\section{Problems of the evaluation of entrepreneurial learning}

What we can assert with certainty is that entrepreneurial learning is a measurable category, which, however, differs from one country to another, from one institution to another, and from one program to another (Charney \& Libecap, 2008; Harrison \& Leitch, 1996; OECD, 2008). Yet, it is difficult to assess the effects of such an education - whether it has sufficiently satisfied the given criteria or not. There is not one approach to the evaluation of entrepreneurship education. All providers of such education should be taken into consideration; programs should be studied and their goals should be taken into account, after which the successfulness of suchlike programs should be assessed through the results achieved by young entrepreneurs. So, there are such evaluations on the one side that observe effects through the raised awareness of entrepreneurship, on the one hand, and the others that would rather measure effects of new businesses formed by those young people, on the other. The third direction in the evaluation is the introduction of a control group which has not had any entrepreneurship education and has not been compared with the primary group (OECD, 2009).

Yet another problem is the comparison of primary, secondary and higher education through the effects of entrepreneurial learning (European Commission, 2012). All these educational institutions have an impact on creation of SME (Kahrović, 2020), which affect employment growth, especially in developing countries (Simonović et al., 2017). European countries have mainly defined the specific outcomes of learning for entrepreneurship education through competences (Nešić et al., 2019). The key competence of entrepreneurship belongs to the group of transversal competences (Bacigalupo et al., 2016). This competence is specific in that it connects the acquisition of knowledge, skills and attitudes with their practical application. In primary education, the positive result of entrepreneurial learning is connected with formed attitudes towards entrepreneurship. In secondary education, all the three dimensions of the outcomes connected with attitudes, knowledge and skills are included (Mohamad et al., 2015). In some countries, only the first two dimensions of the mentioned outcomes are included. Based on all of the foregoing, it is possible to conclude that there is no one uniform system for the monitoring and evaluation of entrepreneurial learning, but there is a defined framework of the indicators for the activities of entrepreneurial learning and benefits generated from entrepreneurial learning (Morselli, 2019). Yet, the indicators that would base the competences of entrepreneurial learning upon the direct assessment of the learning outcomes are still missing. The 
outcomes pertaining to the types of the knowledge of the possibilities for professional orientation and familiarity with the business environment create a framework picture of entrepreneurship, employment possibilities and the obstacles they are to face (Bobić, 2017). There are numerous studies applying advanced methodologies for measuring the efficiency of entrepreneurship education in the OECD countries through the evaluation of programs for raising entrepreneurial awareness amongst the young (Athayde 2009; Souitaris et al. 2007; Oosterbeek et al. 2010; Peterman, Kennedy, 2003). The results of the studies mainly suggest that entrepreneurship education plays a big role in the development of entrepreneurial intentions in young people. In the continuation of the paper, this direct assessment of learning through the development of entrepreneurial awareness amongst young people is applied (Petrović, 2019).

\section{Research methodology}

Based on the theoretical approach to the problem, quite a clear idea about the subject matter of the research is derived. In this paper, a step forward was made in the assessment of the achievement of the first goal of the mentioned program - the raised awareness of entrepreneurship (the understanding of the notion of entrepreneurship) - through the analysis of the formed attitudes and acquired base types of knowledge of those participating in the survey on entrepreneurship. Suchlike direct examinations of the outcomes of entrepreneurial learning that are related to the types of the knowledge of possibilities for professional orientation and becoming familiar with the business environment (Mušikić et al., 2017a), the created framework picture of entrepreneurship, possibilities for employment and the obstacles they are to face produce new indicators for the competences of entrepreneurial learning.

\subsection{The goal, tasks and basic hypotheses of the research}

The goal of the research is to obtain a more relevant picture of the effects of the applied entrepreneurial learning concept in primary and secondary education. Hytti and O'Gorman (2004) and Storey (2000) suggest the following goals that should be achieved by different entrepreneurial learning program schemes: (a) understanding the notion of entrepreneurship, (b) the preparation of an individual for starting a new business, (c) equipping an individual with new skills and approaches. Based on the defined goal and subject matter of the research, the following research tasks were singled out:

- to determine the assessment of the framework knowledge of the participants in the survey of possibilities for professional orientation;

- to determine the assessment of the business environment of the participants in the survey;

- to determine the assessment of the participants in the survey of employment possibilities;

- to determine the assessment of the participants in the survey of the obstacles to starting a business, and

- to determine the framework knowledge of the participants in the survey of programs for active support to young entrepreneurs. 
The research began from the basic hypothesis that entrepreneurship education in secondary- and higher-education institutions has an important influence on the raised awareness of and the basic types of knowledge acquired about entrepreneurship. Out of the basic hypothesis set like this, several individual hypotheses arise. The indirect indicators used were gender and education level, i.e. the difference in the answers given by the respondents was considered according to their gender and the school they attend (secondary school or school of vocational studies).

1. There are statistically significant differences in the knowledge of the term entrepreneurship given education level and gender.

2. There are statistically significant differences in the knowledge of youth entrepreneurship given education level and gender.

3. There are statistically significant differences in the knowledge of active measures given the education level and the sex.

4. There are statistically significant differences in the initiative for performing the entrepreneurial activity given education level and gender.

5. There are statistically significant differences in the rating of the conditions for performing the entrepreneurial activity in Serbia given education level and gender.

During the testing of an assertion or assumption, we start from the assumption that the zero hypothesis is true and, on a sample, we look for empirical evidence against the zero hypothesis. If we find them, then we will reject the zero hypothesis and adopt an alternative one, and vice versa. A positive outcome of the research would be if the respondent recognizes what to be an entrepreneur means; if he/she can develop an entrepreneurial idea; if he/she understands obstacles in the environment; if he/she can rate his/her preferences in his/her entrepreneurial action.

\subsection{The research method, techniques and instruments}

Based on the defined subject matter of the research, the questions to which the respondents answered through self-evaluation filling out the survey forms were isolated. The data obtained were processed both qualitatively and quantitatively, whereas the results are presented textually and tabular. The data obtained by the survey questionnaire were processed by the descriptive statistics method. The IBM SPSS 23 statistical tool and the $\chi 2$ test methods were used in the analysis of the obtained data. The $\chi 2$ test method is used in the majority of cases if qualitative data are concerned. The basic research data may be measurement values, but only their frequencies are entered into the $\chi 2$ test. This is a very practical test which may serve when we want to determine whether some of the obtained (observed) frequencies deviate from the frequencies we would likely expect under a certain hypothesis or not. With this test, we sometimes want to come to know if there is connectedness between two variables, by which we generate the probability of such connectedness. 


\subsection{The sample and research organization}

The conducted survey included 333 respondents, of whom $63.7 \%$ were the students of the Business School of Applied Studies, and $121(36.3 \%)$ were the pupils of the secondary vocational school for economics and trade. The respondents were from $16(1.8 \%)$ to 25 years of age $(0.9 \%)$. The largest number of the respondents were those of $18(20.7 \%), 20$ $(18.0 \%)$ and $21(16.8 \%)$ years of age. Although the sample has certain elements of a stratified quota sample, it is basically suitable (Kulić, 1998). The survey was conducted on the territory of the cities of Jagodina, Dimitrovgrad, Blace and Stara Pazova. The examination was carried out in October 2018. The respondents had enough time to answer the questions posed. The questions were of the closed-ended type. The survey process was anonymous and performed via a questionnaire, on a sheet of paper. The defined questions to which the respondents answered are as follows:

1. Are you familiar with the term entrepreneurship?

2. Have you participated in the Youth Entrepreneurship Program?

3. How familiar are you with the stimulating measures of the Republic of Serbia?

4. Have you got an idea for doing business?

5. Are there conditions for performing the entrepreneurial activity in Serbia?

The first four questions have a possibility of a double-meaning answer ("yes" or "no"), and the question on the conditions for performing the entrepreneurial activity is of a Likert type.

\section{Results of the analysis}

a) Are you familiar with the term entrepreneurship?

At the beginning of the survey, we were interested in whether young people were familiar with the term/notion of entrepreneurship. The survey allows us to notice that the majority of the respondents are familiar with the term entrepreneurship $(80.8 \%)$, but we consider it to be an insufficient number, taking into consideration the fact that those are vocational schools of economics.

Table 1: Familiarity with the term entrepreneurship according to the education level

\begin{tabular}{|l|c|c|c|}
\hline \multirow{2}{*}{ School } & \multicolumn{2}{|c|}{$\begin{array}{c}\text { Are you familiar with the term } \\
\text { entrepreneurship? }\end{array}$} & \multirow{2}{*}{ Total } \\
\cline { 2 - 3 } & YES & NO & \\
\hline Secondary school, \% & $99(81.8 \%)$ & $22(18.2 \%)$ & $149(100.0 \%)$ \\
\hline School of vocational studies, $\%$ & $170(80.2 \%)$ & $42(19.8 \%)$ & $184(100.0 \%)$ \\
\hline$\Sigma, \%$ & $269(80.8 \%)$ & $64(19.2 \%)$ & $333(100.0 \%)$ \\
\hline
\end{tabular}

Source: the authors

Approximately the same percentage of the respondents from the secondary school and the school of vocational studies are familiar with the term entrepreneurship. The secondary school respondents account for $81.8 \%$ and those from the school of vocational studies account for $80.2 \%$. In the next diagram, we examine whether there is a statistically significant difference in the frequencies to the question: are you familiar with the term entrepreneurship in relation to the sex? 
Table 2: The differences in familiarity with the term entrepreneurship according to the sex

\begin{tabular}{|c|c|c|}
\hline $\mathrm{F}$ & $\mathrm{df}$ & $\mathrm{p}$ \\
\hline 10.102 & 1 & 0.01 \\
\hline
\end{tabular}

Source: the authors

Statistically significant differences were seen in the respondents' answers to the question whether they were familiar with the term entrepreneurship or not, depending on whether they were members of the male or female population. The frequencies in understanding the notion of entrepreneurship significantly differ between the males and females $(\mathrm{p}=0.01)$. The hypothesis stating that there are no differences in answers according to gender is refuted.

b) During your schooling, have you participated in Youth Entrepreneurship projects?

The question about the participation in Youth Entrepreneurship projects adds on to the question about familiarity with the term entrepreneurship. The results show that, out of the 269 answers, 32 (i.e. $11.9 \%$ of the) respondents have participated in some of the projects implemented with the aim of developing entrepreneurial culture and climate. A total of $26.8 \%$ of them, however, have never heard of the project. The proportional presentation is given in the following table.

Table 3: During your schooling, have you participated in Youth Entrepreneurship projects?

\begin{tabular}{|l|c|c|}
\hline Participated in Youth Entrepreneurship projects & Number & $\%$ \\
\hline Yes & 32 & 11.9 \\
\hline No & 165 & 61.3 \\
\hline I have never heard of the project & 72 & 26.8 \\
\hline$\Sigma$ & 269 & 100.0 \\
\hline
\end{tabular}

Source: the authors

Participation in Youth Entrepreneurship projects is more present in the secondary school since the curricula are also adapted to the significance of entrepreneurship in solving young people's problems on the labor market. Yet, only $11.9 \%$ of the respondents affirmatively answered that they were familiar with that project, whereas as many as $61.3 \%$ answered they had never heard of that project. In the graph below, a proportional presentation of the participants in the survey and their familiarity with the active measures of the Republic of Serbia, with the previous condition of familiarity with the term entrepreneurship, is given.

c) How familiar are you with the stimulating measures of the Republic of Serbia?

Table 4: The respondents' familiarity with the active measures of the RoS

\begin{tabular}{|l|c|c|}
\hline Familiar with stimulating measures in the RoS & Number & $\%$ \\
\hline Not familiar at all & 80 & 29.6 \\
\hline Partly familiar & 172 & 63.7 \\
\hline Familiar & 18 & 6.7 \\
\hline$\Sigma$ & 270 & 100.0 \\
\hline
\end{tabular}

Source: the authors 
The answers show that only $6.7 \%$ of the respondents are familiar with the stimulating measures for young people, and as many as $63.7 \%$ are partly familiar. The data showing that a larger number of the respondents are not familiar at all with stimulating measures for young people is concerning. In the following two tables (Tables 5 and 6), the analysis of familiarity with active measures according to gender and school allows for the conclusions pertaining to which of those two sub-indicators has a decisive role.

Table 5: Differences in familiarity with active measures according to the education level

\begin{tabular}{|c|c|c|}
\hline $\mathrm{F}$ & $\mathrm{df}$ & $\mathrm{p}$ \\
\hline 0.14 & 2 & 0.93 \\
\hline
\end{tabular}

Source: the authors

As the value of the test statistics $p=0.93$ is greater than 0.05 , there are no significant differences in the knowledge of active measures in relation to the education level. The respondents of both educational institutions share the same fate as far as the prior knowledge of active measures is concerned. Here, the statistics indicate a shortcoming of our educational system when the question about entrepreneurial learning is concerned.

Table 6: Differences in familiarity with active measures according to the sex

\begin{tabular}{|c|c|c|}
\hline $\mathrm{F}$ & $\mathrm{df}$ & $\mathrm{p}$ \\
\hline 3.718 & 2 & 0.15 \\
\hline
\end{tabular}

Source: the authors

Also, due to a high $\mathrm{p}$ value of the test statistics $(\mathrm{p}=0.16>0.05)$, there are no significant differences in the knowledge of active measures in relation to the sex. This finding is not a surprise; namely, the education level should make a more significant difference. The difference between genders is consequently even less relevant.

d) Have you got an idea for doing business?

One's finishing secondary or higher education is a step towards the entrance to the labor market. The question: how ready young respondents are to integrate in the business environment can be seen through their having ideas about starting their own business.

The figure showing whether young people have an idea for starting a new business is dominant. As many as $63.5 \%$ of the respondents answered positively. The least percentage, i.e. $10.33 \%$ of them, have no idea at all for starting a new business. In the following tables, whether there is a significant difference among the respondents of the male and those of the female gender, and secondary and higher education in having an idea for doing business, or not, is the subject matter of consideration. 
Graph 1: Having an idea for doing business on one's own

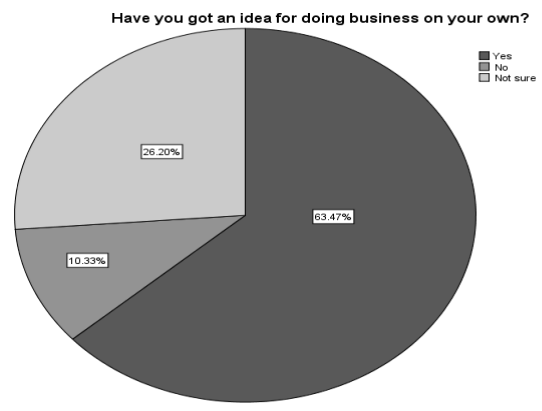

Source: the authors

Table 7: The difference in having an idea for doing business on one's own, according to the sex

\begin{tabular}{|c|c|c|}
\hline $\mathrm{F}$ & $\mathrm{df}$ & $\mathrm{p}$ \\
\hline 18.444 & 2 & 0.00 \\
\hline
\end{tabular}

Source: Author

Table 8: The difference in having an idea for doing business on one's own, according to the education level

\begin{tabular}{|c|c|c|}
\hline $\mathrm{F}$ & $\mathrm{df}$ & $\mathrm{p}$ \\
\hline 0.034 & 2 & 0.98 \\
\hline
\end{tabular}

Source: the authors

As the value of the test statistics $\mathrm{p}=0.98$ is, therefore, greater than 0.05 , no statistically significant difference is found in having an idea for starting one's own business according to the education level, by the $\chi 2$ test method. It is possible to conclude that the respondents' years of age are not an obstacle to creativity and a wish for making a success on their own. The difference between genders regarding this question has a bigger and significant influence.

e) Are there conditions for performing entrepreneurial activity in Serbia?

This question served the participants in the survey to recognize the business environment which they live and will work in. Entrepreneurial learning is aimed at making attendees familiar with the options offered regarding employment, the recognition of a favorite climate for the development of business, creativity and innovativeness in knowing their way around in the given circumstances.

The respondents participating in this survey answered in the following way: $56.09 \%$ of them said they had no opinion on the existence of the conditions for business in Serbia; $21.4 \%$ of the respondents found that such conditions are present but partly, whereas $15.37 \%$ of them said there were no conditions for starting a small business. Through a further analysis, we examined whether there was a difference in the respondents' opinions on the existence of the conditions for the development of private business classified according to the sex and the education level. A statistically significant difference was found in the respondents' answers in relation to the sex, $\mathrm{p}=0.00(\mathrm{~F}=15.426, \mathrm{df}=1)$. 
Graph 2: Are there conditions for performing the entrepreneurial activity in Serbia?

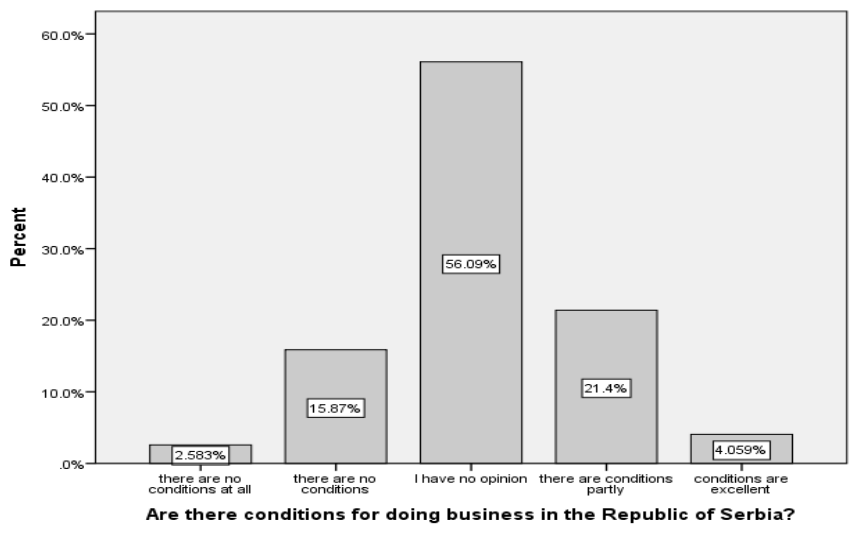

Source: the authors

\section{Conclusion}

Given the fact that these are schools of the economic path, the results are not positive when speaking about the present model of entrepreneurship education. The respondents demonstrate an unenviable level of raised entrepreneurial awareness and the insights gained into the entrepreneurial environment. The results show that there is no bigger difference between the answers of both genders regarding familiarity with stimulating measures directed towards the development of entrepreneurship in Serbia. Participation in Youth Entrepreneurship projects is more present in the secondary school, since the curricula are also adapted to the significance of entrepreneurship in solving young people's problems on the labor market. Yet, only $11.9 \%$ of the respondents answered affirmatively that they were familiar with that project, whereas as many as $61.3 \%$ of them had never heard of that project. The frequency in the answers shows that a low percentage of young people are familiar with active measures (7.61\%), and as many as $63 \%$ of the young are only partly familiar with the stimulating measures intended for your people to start a business. There are no significant differences, either, in the knowledge of active measures in relation to the professional qualification level. The respondents in the higher-education institution do not receive a more significant prior knowledge of active measures in relation to the secondary school students, which could be said to be a shortcoming of our school system. A better coordination of the young and their better knowledge of information about the implementation of financial and nonfinancial aid and support within the framework of the existing entrepreneurial learning programs are necessary. In the schooling process, there is a need for a greater presence of young peoples' knowledge of information and the development of business ideas for their becoming independent on the labor market.

Based on the question about familiarity with the notion of entrepreneurship, a statistically significant difference is found in understanding the notion between the male and female sexes. This difference in the answers of the respondents of the male and female 
sexes is also found in their expressing their opinions on the conditions for the development of business in Serbia. A statistically significant difference is also found in having an idea for doing business on one's own between the male and female sexes. We may assume that this result has a psychological underlying concept in the sexes' inclination towards risk. Women are much more precarious than the male sex in expressing their ideas and readiness to start their own business. Although efforts are made towards the equality of both sexes on the labor market, women still feel greater precariousness in the implementation of their business ideas and starting their own business (Beraha, Đuričin, 2020). No significant difference was found between the respondents of a different professional qualification degree as per idea for starting own business. We can conclude that the respondents' years of age are not an obstacle to creativity and a wish for a success made on their own. The difference in the sexes has a greater influence when this question is concerned.

The results of the survey research suggest that we should think about a different development of entrepreneurial culture and skills, redefine the goal and tasks of entrepreneurship education by appreciating the specificities and needs of young people potential entrepreneurs. A need is born for revising the existing syllabi and content, as well as for "a potential change in the teaching strategy through didactic systems, working methods, approaches, through changes in the interpersonal relationships between the main actors in the teaching process (pupils/students and teachers), especially so in relation to the approach to work on teaching content" (Kačapor, 2012).)

\section{References}

Adebiyi, A. \& Adegbemi, O. (2013). Intellectual entrepreneurship: theories, purpose and challenges. International Journal of Business Administration, 4(5), 30-37. Doi: http://dx.doi.org/10.5430/ijba.v4n5p30

Athayde, R. (2009). Measuring enterprise potential in young people. Enterpreneursip Theory and Practice, 33(2), 481-500. Doi: https://doi.org/10.1111\%2Fj.15406520.2009.00300.x

Bacigalupo, M., Kampylis, P., Punie, Y.\& Van den Brande, G. (2016). EntreComp: The Entrepreneurship Competence Framework. Luxembourg: Publication Office of the European Union. Doi: https://doi.org/10.2791/593884

Beraha, I., \& Đuričin, S. (2020). Istraživanje potencijala za razvoj inovativnog ženskog preduzetništva u Srbiji. Ekonomika, 66(1), 93-104. Doi: https://doi.org/10.5937/ekonomika2001093B

Bjekić, R., \& Strugar Jelača, M. (2019). Students'entrepreneurial intention in respect to their psychological traits, gender and study program of the faculty. Teme, 43(2), 375-394. Doi: https://doi.org/10.22190/TEME180213024B

Bobić, D. (2017). Mapiranje prepreka za preduzetništvo mladih. Beograd: Centar za visoke ekonomske studije.

Charney,A., \& Libecap, GD. (2008). The Impact of Entrepreneurship Education: An 
Evaluation of the Berger Entrepreneurship Program at the University of Arizona, Kaufman Center for Entrepreneurship Learning, 1985-1999, Retrieved June 2018, from https://papers.ssrn.com/sol3/papers.cfm?abstract id=1262343

Chigunta, F. (2001). Youth Livelihoods and Enterprise Activities in Zambia. Report to IDRC. Canada.

Erić-Nielsen, J., Stojanović-Aleksić, V., \& Zlatanović, D. (2019). Izazovi upravljanja preduzetničkom organizacijom. Ekonomika, 65(2), 87-98. Doi: https://doi.org/10.5937/ekonomika1902087E

European Commission. (2012). Entrepreneurship Education at School in Europe National Strategies, Curricula and Learning Outcomes. EACEA P9 Eurydice and Policy Support.

Eurydice Q\&A on Entrepreneurship Education at School in Europe; Flash Eurobarometer. (2008). OECD Programme for International Student Assessment (PISA).

Harrison, B., \& Leitch, I. (1996). Learning organizations: the measurement of company performance. Journal of European Industrial Training, 20(1), 31-44. Doi: https://doi.org/10.1108/03090599610105264

Hytti, U., \& O'Gorman, C. (2004). What is 'enterprise education'? an analysis of the objectives and methods of enterprise education programmes in four European countries. Education + Training, 46, 11-23. Doi: https://doi.org/10.1108/00400910410518188

International Labor Organisation. (2015). Global employment trends for youth 2015. Geneva: International Labor Organisation.

Kačapor, S. Z. (2012). Preduzetništvo kao cilj i ishod vaspitanja i obrazovanja. Zbornik radova Filozofskog fakulteta u Prištini, 42(1), 69-96.

Kahrović, E. (2020). Preduzetnički univerziteti i posredničke organizacije kao faktor uspešnosti malih i srednjih preduzeća - pregled literature. Ekonomika preduzeća, 68(3-4), 229-247. Doi: https://doi.org/10.5937/EKOPRE2004229K

Kulić, R. (1998). Sadržaj rada i obrazovanje. Beograd: Andragoška biblioteka, Zavod za udžbenike i nastavna sredstva.

Miletić, V., Miletić, S., \& Ćurčić, N. (2018). Profitabilno poslovanje organizacije kao ishod unapređenja konkurentnosti primenom koncepta CRM. Anali Ekonomskog fakulteta u Subotici, 40, 33-48.

Mohamad, N., Lim, H.-E., Yusof, N., \& Soon, J.-J. (2015). Estimating the effect of entrepreneur education on graduates' intention to be entrepreneurs. Education + Training, 57(8/9), 874-890. Doi: https://doi.org/10.1108/ET-03-2014-0030

Morselli D. (2019). The assessment of entrepreneurial education. In: The Change Laboratory for Teacher Training in Entrepreneurship Education. Springer, Cham: Springer Briefs in Education. Doi: https://doi.org/10.1007/978-3-030-02571-7_2

Mušikić, S., Marčetić, M., \& Đurović, S. (2017b). The role of the active policy of the labor 
market in the Republic of Serbia. Ekonomika, 63(2), 79-86. Doi: https://doi.org/10.5937/ekonomika1702079M

Mušikić, S., Mitrović, S., \& Marčetić, M. (2017a). Neformalna zaposlenost mladih u Srbijistanje i trendovi. Ekonomija - teorija $i$ praksa, 10(4), 65-75. Doi: https://doi.org/10.5937/etp1704067M

Nešić, M., Zubanov, V., \& Mišković, I. (2019). Preduzetništvo u turizmu kao izbor profesionalnog usmerenja mladih. TIMS Acta, 13(2), 69-78. Doi: https://doi.org/10.5937/timsacta1902069N

OECD. (2009). Evaluation of Programmes Concerning Education for Entrepreneurship, report by the OECD Working Party on SMEs and Entrepreneurship, OECD.

Oosterbeek, H., Praag, M., \& Ijsselstein, A. (2010). The impact of entrepreneurship education on entrepreneurship skills and motivation. European Economic Review, 54(3), 442-454. Doi: https://doi.org/10.1016/j.euroecorev.2009.08.002

Peterman, N., \& Kennedy, J. (2003). Enterprise education: influencing students' perceptions of entrepreneurship. Sage Journals, 28(2), 129-144. Doi: https://doi.org/10.1046\%2Fj.1540-6520.2003.00035.x

Petrović, M., \& Leković, B. (2019). Characteristics of ambitious entrepreneurs in Southeast Europe region: High-growth expectation concept. Anali Ekonomskog fakulteta u Subotici, 41, 55-66. Doi: https://doi.org/10.5937/AnEkSub1941055P

Schnurr, J., \& Newing, S. (1997). A Conceptual and Analytical Framework for Youth Enterprise and Livelihood Skills Development: Defining an IDRC Niche. IDRC, Canada.

Simonović, Z., Ćurčić, N., \& Miletić, V. (2017). Neki problemi razvoja malih i srednjih preduzeća u poljoprivredi Srbije. Anali Ekonomskog fakulteta u Subotici, 37, 57-69.

Souitaris, V., Zerbinati, S., \& Al-Laham, A. (2007). Do entrepreneurship programmes raise entrepreneurial intention of science and engineering students? The effect of learning, inspiration and resources. Journal of Business Venturing, 22(4), 566-591. Doi: https://doi.org/10.1016/j.jbusvent.2006.05.002

Storey, D. J. (2000). Small Business: Critical Perspectives on Business and Management. London and New York: Taylor and Francis Group.

Xingjian,W., Xiaolang, L., \& Jian,S. (2019). How does the entrepreneurship education influence the students' innovation? Testing on the multiple mediation. Frontiers in Psychology, 10, 1557. Doi: https://dx.doi.org/10.3389\%2Ffpsyg.2019.01557 